\title{
Estimasi Curah Hujan Radar Cuaca dengan Hubungan Z-R Berbeda pada Tipe Awan Hujan Konvektif dan Stratiform di Lampung
}

\author{
Lilik Ardiyanto ${ }^{1}$, Anggi M. Hanif ${ }^{2}$, Muhammad Alfaridzi ${ }^{3}$, Sony Ariwibowo ${ }^{4}$, Eko \\ Wardoyo $^{5}$, Imma Redha Nugraheni ${ }^{6}$ \\ ${ }^{1,2,3,4,6}$ Sekolah Tinggi Meteorologi Klimatologi dan Geofisika, Jalan Perhubungan I No.5 Pondok \\ Betung, Pd. Aren, Tangerang Selatan \\ ${ }^{5}$ Badan Meteorologi Klimatologi dan Geofisika, Jl. Angkasa I No.2 Kemayoran, Jakarta Pusat, DKI \\ Jakarta
}

Email: lilikardi97@gmail.com

\begin{abstract}
Weather radar is used to cover the lack of measurement due to the precision of the amount of rainfall gauges. Products on the weather radar produce reflectivity data $(Z)$, so to get rainfall estimation data processing is required with the reflectivity $(Z)$ and rain rate $(R)$ or $Z-R$ relationships. The Z-R relationship can be different in every condition. One of the influences is the type of rain clouds, namely convective and stratiform. This study aims to determine the relationship of $Z-R$ and radar products that are more suitable for use in Lampung. The study was conducted by classifying the type of rain cloud based on rain rate, then produced CMAX, CAPPI, SRI and RIH radar products at the time of the rain. Next, a comparison of rainfall events from convective and stratiform rain cloud types from actual rain events to radar estimation results using the Z- $R$ relationship from Marshall-Palmer, Rosenfeld Tropical and WSR-88D Convective. The results show that SRI products are most suitable for the case of rain from convective clouds, while CMAX products are more suitable for stratiform rain cloud types. Then it can be seen that there are different uses of Z$R$ relationships in different types of rain clouds. Convective cloud type is more suitable to use the Z- $R$ WSR-88D Convective ( $W-C)$ and Marshall Palmer $(M-P)$ relationship is more suitable for stratiform cloud type.
\end{abstract}

Keywords : Convective, Stratiform, Marshall-Palmer, Rosenfeld Tropical, WSR-88D Convective

\begin{abstract}
ABSTRAK: Radar cuaca digunakan untuk menutupi kekurangan pengukuran karena ketebatasan jumlah alat pengukur curah hujan. Produk pada radar cuaca menghasilkan data reflektivitas (Z), sehingga untuk mendapatkan data estimasi curah hujan diperlukan pengolahan dengan hubungan reflektivitas $(Z)$ dan rain rate $(R)$ atau hubungan $Z-R$ yang dapat berbeda pada setiap kondisi. Salah satu yang mempengaruhi adalah tipe awan hujan yaitu konvektif dan stratiform. Penelitian ini bertujuan untuk mengetahui hubungan Z-R dan produk radar yang lebih cocok digunakan pada daerah Lampung. Penelitian dilakukan dengan mengklasifikasikan tipe awan hujan berdasarkan rain rate, kemudian dihasilkan produk-produk radar CMAX, CAPPI, SRI dan RIH. Selanjutnya dilakukan perbandingan kejadian hujan sebenarnya dari tipe awan konvektif dan stratiform dengan hasil estimasi radar dengan menggunakan hubungan Z-R dari Marshall-Palmer, Rosenfeld Tropical dan WSR-88D Convective. Hasil penelitian menunjukkan produk SRI paling cocok digunakan untuk kasus hujan dari awan konvektif, sedangkan produk CMAX lebih cocok untuk tipe awan stratiform. Diketahui bahwa terdapat penggunaan hubungan Z-R berbeda pada tipe awan hujan yang berbeda. Untuk tipe awan konvektif lebih cocok menggunakan hubungan Z-R WSR-88D Convective (W-C) dan Marshall Palmer (M-P) lebih cocok untuk tipe awan stratiform.
\end{abstract}

Kata Kunci : Konvektif, Stratiform, Marshall-Palmer, Rosenfeld Tropical, WSR-88D Convective 


\section{PENDAHULUAN}

Dalam meteorology dikenal parameter presipitasi yang menunjukkan jumlah hujan yang jatuh dari atmosfer ke permukaan bumi yang pada daerah tropis lebih kita kenal sebagai curah hujan (triadmodjo, 2008). Parameter curah hujan ini menjadi satu diantara parameter penting dalam meteorology Indonesia untuk keperluan mitigasi, pertanian perkebunan, maupun perikanan (Waskita, 2017). Pengukuran curah hujan dapat dilakukan dalam berbagai metode, baik dengan pengukuran konvensional maupun otomatis. Namun, tidak semua tempat tersedia pengukuran curah hujan sehingga beberapa tempat tidak dapat teramati. Untuk mengetahui distribusi curah hujan yang tidak teramati tersebut, digunakanlah teknologi penginderaan jarak jauh yaitu radar (Radio Detecting and Ranging) dan satelit. Menurut Wardoyo (2015), radar mendeteksi fenomena di atmosfer dengan cara meradiasikan energi gelombang elektromagnetik dan menangkap serta mengukur pantulan energi (reflektivitas) gelombang elektromagnetik tersebut. Data yang dihasilkan oleh pengoprasian radar adalah data reflekstivitas $(Z)$. Nilai reflektivitas yang sama belum tentu menunjukan nilai distribusi curah hujan yang sama pula, untuk itu diperlukan ralasi hubungan $Z-R$ (reflectivitas dan rain rate) untuk mengetahui estimasi curah hujannya. Hubungan $Z-R$ yang digunakan untuk mengestimasi curah hujan ini memiliki variabilitas tinggi berdasarkan waktu dan tempat (Alfieri et al., 2010). Nzeoukou dan Sauvageot (2004) dalam penelitiannya menyebutkan bahwa tipe awan hujan dapat secara signifikan mempengaruhi hubungan Z-R dengan mengklasifikasikan tipe awan hujan menjadi konvektif dan stratiform menunjukan nilai konstanta empiris dari kedua tipe awan hujan tersebut. Menurut Tokay dan Short (1996), ukuran tetes pada hujan dari awan Stratiform dominan lebih besar dari konvektif dengan jumlah yang sedikit, sedangkan pada hujan dari awan konvektif, ukuran tetesnya lebih kecil dari stratiform namun memiliki jumlah yang banyak. Penggunaan hubungan Z-R menggunakan rekomendasi ROC (1999) dengan tipe awan hujan stratiform menggunakan Marshall-Palmer, kemudian untuk sistem konvektif pada area tropis menggunakan Rosenfeld Tropical dan untuk awan konvektif kuat menggunakan WSR-88D Convective. Hubungan Z-R yang secara deflaut digunakan tanpa memperhatikan tipe awan hujan pada wilayah Indonesia oleh radar cuaca BMKG (Badan Meteorologi Klimatologi dan Geofisika) adalah hubungan Z$\mathrm{R}$ dari Marshall-Palmer (Kusuma, 2016). Hal ini tentu dapat menyebabkan pengestimasian curah hujan yang kurang tepat, misalnya curah hujan underestimate (nilai di bawah curah hujan actual) atau overestimate (nilai di atas curah hujan actual).

Berdasarkan latar belakang tersebut, dilakukan penelitian ini dengan tujuan untuk mengetahui hubungan Z-R dan produk radar yang cocok digunakan untuk estimasi curah hujan pada radar di daerah lampung berdasarkan tipe awan hujan konvektif dan stratiform.

\section{DATA DAN METODE PENELITIAN}

\subsection{Data}

\subsubsection{Data Hujan}

Data hujan yang digunakan dalam penelitian ini adalah data penakar curah hujan otomatis ARG yang ada di dalam jangkauan pengamatan radar cuaca Lampung di 4 titik dalam radius kurang dari $100 \mathrm{~km}$ pada bulan januari, Februari, Maret dan April dimana bulan januari dan Februari mewakili musim hujan dimana dominan terbentuk tipe awan hujan Stratiform dan Maret dan April mewakili periode peralihan dimana umumnya terbentuk tipe awan hujan 
konvektif. Data tersebut diambil dari AWS Center BMKG. Adapun nama dan letak koordinat masing-masing penakar hujan dtunjukkan pada tabel 1.

Data hujan yang digunakan merupakan kejadian hujan dalam rentang waktu Bulan 1 Januari 2019 hingga 30 April 2019 dengan interval 1 jam.

Tabel 1. Nama dan lokasi penakar hujan otomatis (ARG) di daerah Lampung

\begin{tabular}{cccc}
\hline No & $\begin{array}{c}\text { Nama Penakar } \\
\text { Hujan }\end{array}$ & Koordinat & $\begin{array}{c}\text { Jarak ke } \\
\text { Radar } \\
(\mathrm{km})\end{array}$ \\
\hline 1 & ARG Bergen & $-5,514841 ; 105,556183$ & 55 \\
2 & ARG Trikora & $-5,26785 ; 105,3033$ & 16 \\
3 & ARG BP3K & $-4,983 ; 105,203$ & 25 \\
4 & ARG Taman Bogo & $-5,00865 ; 105,5032$ & 43 \\
\hline
\end{tabular}

\subsubsection{Data Radar Cuaca}

Data radar yang digunakan adalah raw data Radar Cuaca Stasiun Meteorologi Radin Inten Lampung yang sudah terkonversi dalam .vol Gematronik. Radar Lampung terletak di koordinat -5.2082 LS dan 105.1756 BT dengan elevasi 84 meter. Radar ini merupakan radar doppler merek EEC dengan tipe C-Band dengan polarisasi tunggal. Metode scanning yang diterapkan pada radar cuaca Lampung menggunakan Volume Coverage Pattern (VCP) 21 yang mana dalam satu volume scanning terdapat sebelas elevasi dari $0,5^{\circ}$ hingga $19,5^{\circ}$.

\section{METODE}

Data hujan di klasifikasikan menurut pengklasifikasian jenis awan menurut penelitian Nzeukou dan Sauvageot (2004) dengan perbedaan nilai konstanta empiris rain rate kedua tipe awan pengasil hujan yaitu awan konvektif dengan curah hujan $\geq 10 \mathrm{~mm} / \mathrm{jam}$ dan awan stratiform dengan curah hujan $\leq 10 \mathrm{~mm} / \mathrm{jam}$. Raw data radar Lampung diolah dengan menggunakan software RainDART (Display, Analysis and, Research Tool), kemudian dibuat beberapa produk untuk mengestimasi curah hujan. Beberapa produk yang digunakan sebagai input estimasi curah hujan terdiri dari CMAX (Column Maximum), CAPPI (Constan Altitude $P P I$ ), dan SRI (Surface Rainfall Intensity) akumulasi 1 jam. Produk-produk tersebut kemudian diturunkan menjadi produk RIH (Rainfall Intensity Histogram) untuk mendapatkan nilai akumulasi curah hujan dengan menerapkan hubungan Z-R, yaitu menggabungkan nilai reflektivitas yang dihasilkan radar dengan rain rate yang diukur pada sebuah titik pengamtan dan memasukannta kedalam persamaan hubungan Z-R

$$
Z=a R^{b}
$$

Dimana variabel a mewakili median diameter ukuran droplet dalam satu sampling volume dan variabel $b$ mewakili kondisi equilibrium perubahan ukuran droplet dalam satu sampel volume (Rosenfeld dan Ulbrich, 2002). Hubungan Z-R diatur pada produk SRI. Adapun hubungan Z-R yang digunakan adalah Marshall-Palmer (M-P), Rosenfield Tropical (R-T), dan WSR-88D Convective (W-C) dengan nilai masing-masing nilai hubungan Z-R tertera pada tabel 2.

Tabel 2. nilai setiap variable pada hubungan Z-R yang digunakan

\begin{tabular}{cccc}
\hline No & $\begin{array}{c}\text { Hubungan Z-R } \\
Z=\mathrm{aR}^{\mathrm{b}}\end{array}$ & $\mathrm{a}$ & $\mathrm{b}$ \\
\hline 1 & Marshall-Palmer (M-P), & 200 & 1,6 \\
2 & Rosenfield Tropical (R-T) & 250 & 1,2 \\
3 & WSR-88D Convective (W-C) & 300 & 1,4 \\
\hline
\end{tabular}


Adapun pengaturan yang diterapkan pada setiap produk yang digunakan adalah sebagai berikut:

a. CMAX

Menurut Wardoyo (2015), produk CMAX merupakan produk radar cuaca yang menampilkan reflektivitas maksimum pada suatu kolom pengamatan radar cuaca. Pengaturan dilakukan pada batas atas dan bawah pada produk CMAX seperti pada gambar 1a. Batas atas yang digunakan adalah $4 \mathrm{~km}$ untuk menghindari adanya bright band echo. Sedangkan untuk batas bawah diatur pada $300 \mathrm{~m}$ yang diasumsikan sebagai rata-rata tinggi dasar awan di Kota Bandar lampung.

b. CAPPI

Image dari reflektivitas pada suatu lapisan atmosfer tertentu di atas MSL (Mean Sea Level) dihasilkan oleh algoritma dalam produk Constant Altitude PPI (CAPPI) (Waskita, 2017). Produk CAPPI menggunakan algoritma pseudo CAPPI dan diatur pada ketinggian 0,5 $\mathrm{km}$ ditunjukkan pada gambar $1 \mathrm{~b}$.

c. SRI

Menurut Waskita (2017), citra intensitas hujan pada ketinggian permukaan yang dipilih dihasilkan oleh produk Surface Rainfall Intensity (SRI). Penelitian ini menerapkan tiga jenis hubungan Z-R yang berbeda pada produk SRI dengan menggunakan algoritma pseudo SRI. Oleh karena itu terdapat tiga buah produk SRI dengan hubungan Z-R yang berbeda yang ditunjukkan pada gambar 2a, 2b, dan $2 \mathrm{c}$.

d. RIH

Data time series intensitas curah hujan pada suatu lokasi disediakan oleh produk Rainfall Intensity Histogram (RIH) (Wardoyo, 2015). Image intensitas Produk RIH diatur dengan ratarata horizontal seluas 3 pixel di sekitar titik penakar hujan dengan interval akumulasi 1 jam. Pengaturan pada produk RIH dapat dilihat pada gambar $2 \mathrm{~d}$.

Untuk verifikasi performa estimasi curah hujan radar cuaca di lampung, digunakan perbandingan data pengukuran oleh ARG dengan data estimasi curah hujan oleh radar cuaca dengan menggunakan metode statistik sederhana. Menurut Wilks (1995), Swarinoto dan Sugiyono (2011), perhitungan dengan beberapa metode statistik sederhana tersebut, dapat diketahui besarnya penyimpangan yang terjadi antara estimasi curah hujan radar dengan curah hujan sebenarnya untuk keperluan evaluasi. Perhitungan penyimpangan yang dipakai pada penelitian ini digunakan perhitungan RMSE (Root Mean Square Error) dan MAE (Mean Absolut Error) dan nilai korelasi. Kecenderungan underestimate dan overestimate dapat ditunjukan oleh RMSE dan MAE dimana semakin besar nilainya maka semakin jauh nilai estimasi curah hujan radar dari nilai sebenarnya dan sebaliknya. Sedangkan pada nilai korelasi, semakin besar nilai korelasi maka semakin baik korelasi antara hasil estimasi curah hujan radar dan observasi dengan rentang kelayakan yang terdapat pada tabel 3 .

Tabel 3. Rentang kelayakan nilai korelasi oleh Usman dkk. (2011)

\begin{tabular}{ccc}
\hline No & Nilai Korelasi & Keterangan \\
\hline 1 & 0 & Tidak Berkorelasi \\
2 & $0.01-0.20$ & Sangat rendah \\
3 & $0.41-0.60$ & Agak rendah \\
4 & $0.61-0.80$ & Cukup \\
5 & $0.81-0.99$ & Tinggi \\
6 & 1 & Semakin Tinggi \\
\hline
\end{tabular}




$$
\begin{aligned}
& \text { RMSE }=\sqrt{\frac{\sum_{i=1}^{n}\left(f_{i}-o_{i}\right)^{2}}{n}} \\
& M A E=\frac{1}{n} \sum_{i=1}^{n}\left|f_{i}-o_{i}\right| \\
& r=\frac{\sum\left(f_{i}-\bar{f}\right)\left(o_{i}-\bar{o}\right)}{\sqrt{\sum\left(f_{i}-\bar{f}\right)\left(o_{i}-\bar{o}\right)}}
\end{aligned}
$$

Dengan $\mathrm{n}$ mewakili banyaknya data, $f_{i}$ adalah nilai estimasi hujan ke-i $(\mathrm{mm})$ dan $o_{i}$ mewakili nilai curah hujan sebenarnya atau curah hujan observasi ke-i (mm) dan $\bar{o}$ mewakili curah hujan observasi rata-rata serta $\bar{f}$ mewakili curah hujan rata-rata dari hasil estimasi (Dewi, 2018).

\section{Hasil dan Pembahasan}

Produk-produk radar untuk mengestimasi curah hujan menunjukkan nilai yang cukup seragam satu sama lain yang dapat dilihat dari pola grafik grafik pada gambar 3. Namun secara umum, nilai estimasi curah hujan radar menunjukkan hasil yang undersetimate
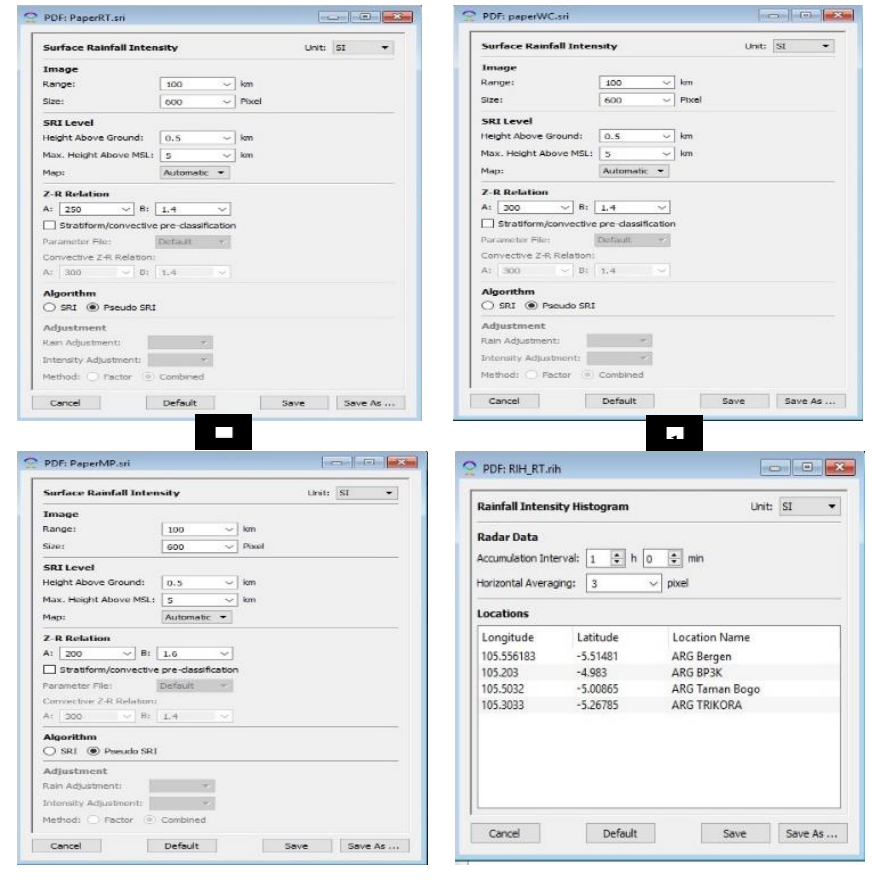

Gambar 2. Pengaturan pada produk SRI dengan hubungan Z-R Rosenfeld Tropical (a), WSR-88D

Convective (b) dan Marshall-Palmer (c) serta pengaturan pada produk RIH (d)

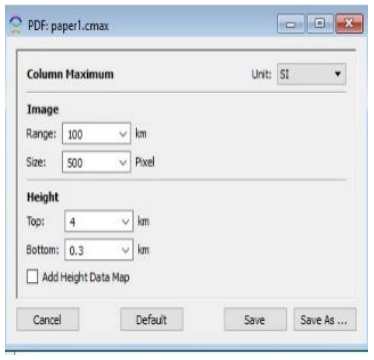

$\mathrm{a}$

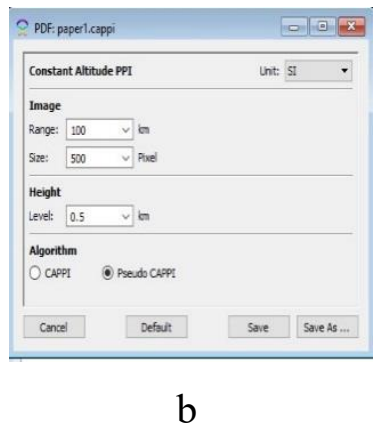

Gambar 1. Pengaturan produk CMax (a) dan produk CAPPI (b)

terhadap curah hujan hasil pengamatan. Banyak kejadian hujan dengan intensitas tinggi yang tercatat pada pengamatan namun radar hanya menghasilkan estimasi curah hujan yang lebih kecil. Bahkan pada beberapa kejadian terdapat perbedaan pola dimana saat curah hujan. Dari grafik pada gambar 3, didapatkan nilai RMSE, MAE dan korelasi dari masing-masing produk di setiap titik pengamatan hujan seperti pada tabel 4. Berdasarkan tabel tersebut, secara keseluruhan semua produk yang digunakan memiliki masing-masing nilai korelasi, RMSE dan MAE yang cukup beragam. Setiap lokasi memiliki produk-produk dengan 
performa terbaik yang berbeda. Pada ARG Bergen nilai korelasi tertinggi ditunjukkan oleh produk SRI-WC dengan nilai 0.42. Sementara itu, nilai RMSE dan MAE masing-masing produk cukup berdekatan satu sama lain. Di lokasi ARG BP3K, performa terbaik ditunjukkan oleh produk CAPPI meskipun nilai korelasi hanya mencapai 0.13 , sedangkan nilai RMSE dan MAE terendah ditunjukkan oleh produk CMAX. Sementara itu, di ARG Taman Bogo,

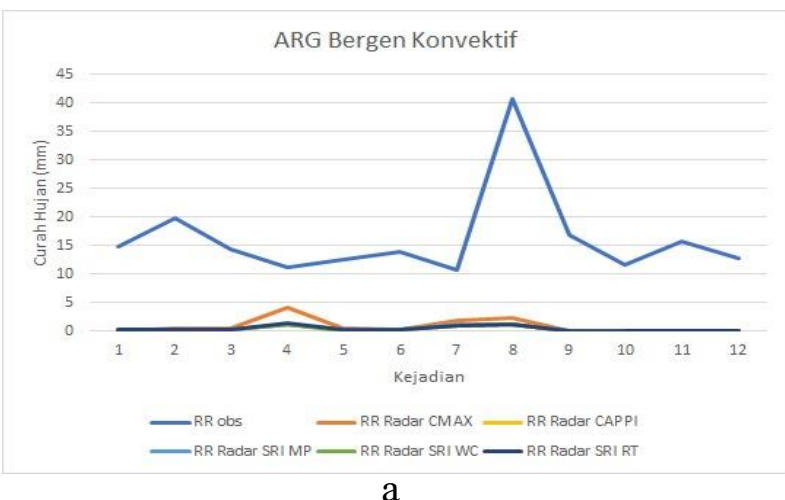

a

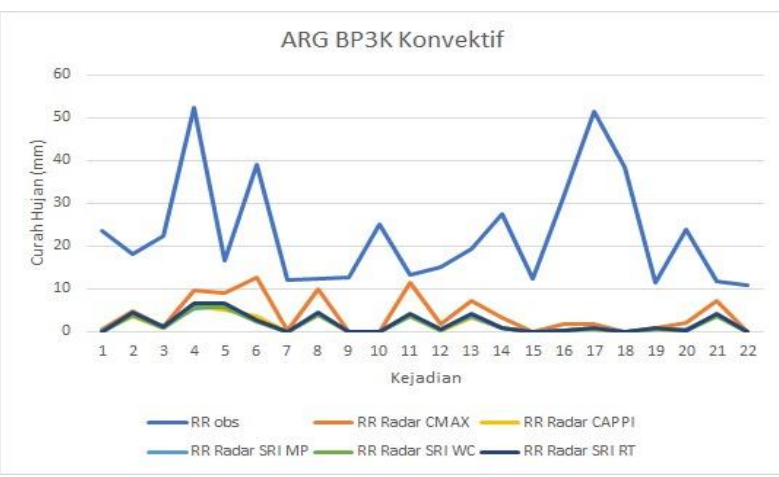

$\mathrm{C}$

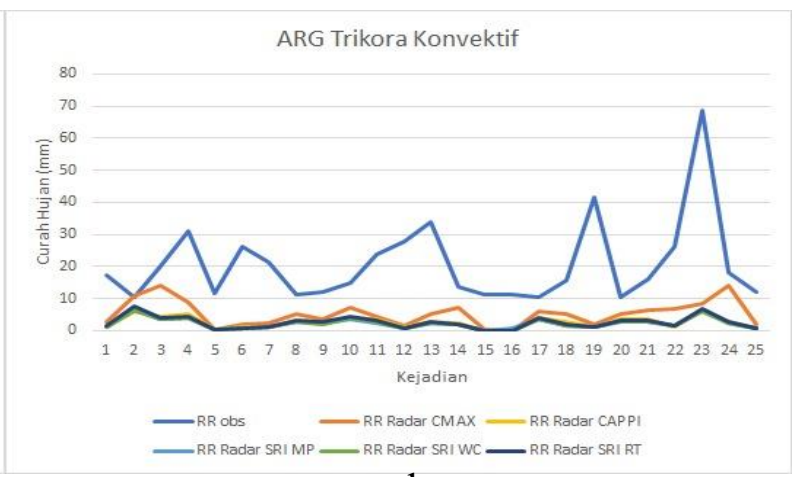

b

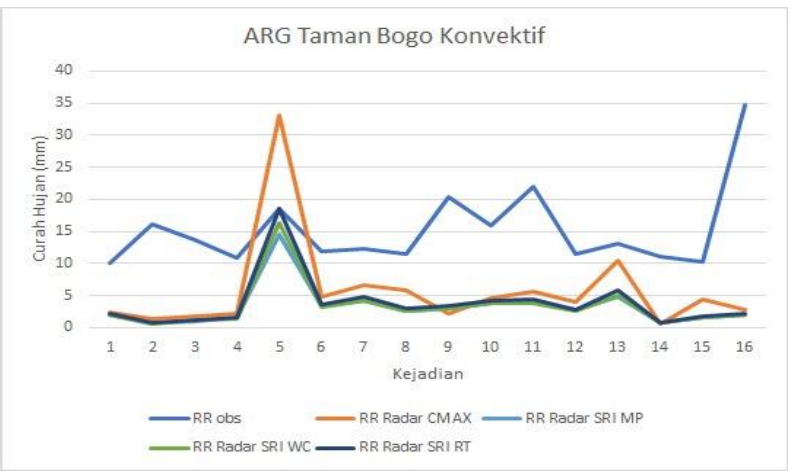

d

Gambar 3. Perbandingan estimasi curah hujan radar dan pengamatan untuk hujan tipe awan konvektif pada masing-masing daerah ARG Bergen (a), ARG Trikora (b), ARG BP3K (c) dan ARG Taman Bogo (d)

performa produk SRI-MP lebih baik dibanding produk-produk lainnya, dengan nilai korelasi 0.155, sedangkan nilai RMSE dan MAE dari produk-produk lain nilai cukup seragam. Terakhir yaitu di ARG Trikora, performa terbaik ditunjukkan oleh produk SRI-MP yang mana nilai korelasinya mencapai 0.32 . sedangkan untuk nilai RMSE dan MAE, masingmasing produk menunjukkan nilai yang cukup seragam. Dari 4 titik pengamatan, hubungan ZR WSR-88D Convective (WC) menunjukkan performa yang lebih baik dibandingkan skema hubungan Z-R Marshall-Palmer (MP) dan Rosenfield Tropical (RT) sesuai dengan teori di atas meskipun pada dasarnya penggunaan hubungan Z-R WSR-88D Convective (WC) berdasarkan pada daerah lintang menengah. 
Tabel 4. nilai RMSE, MAE dan korelasi dari masing-masing produk di setiap titik pengamatan pada tipe awan konvektif

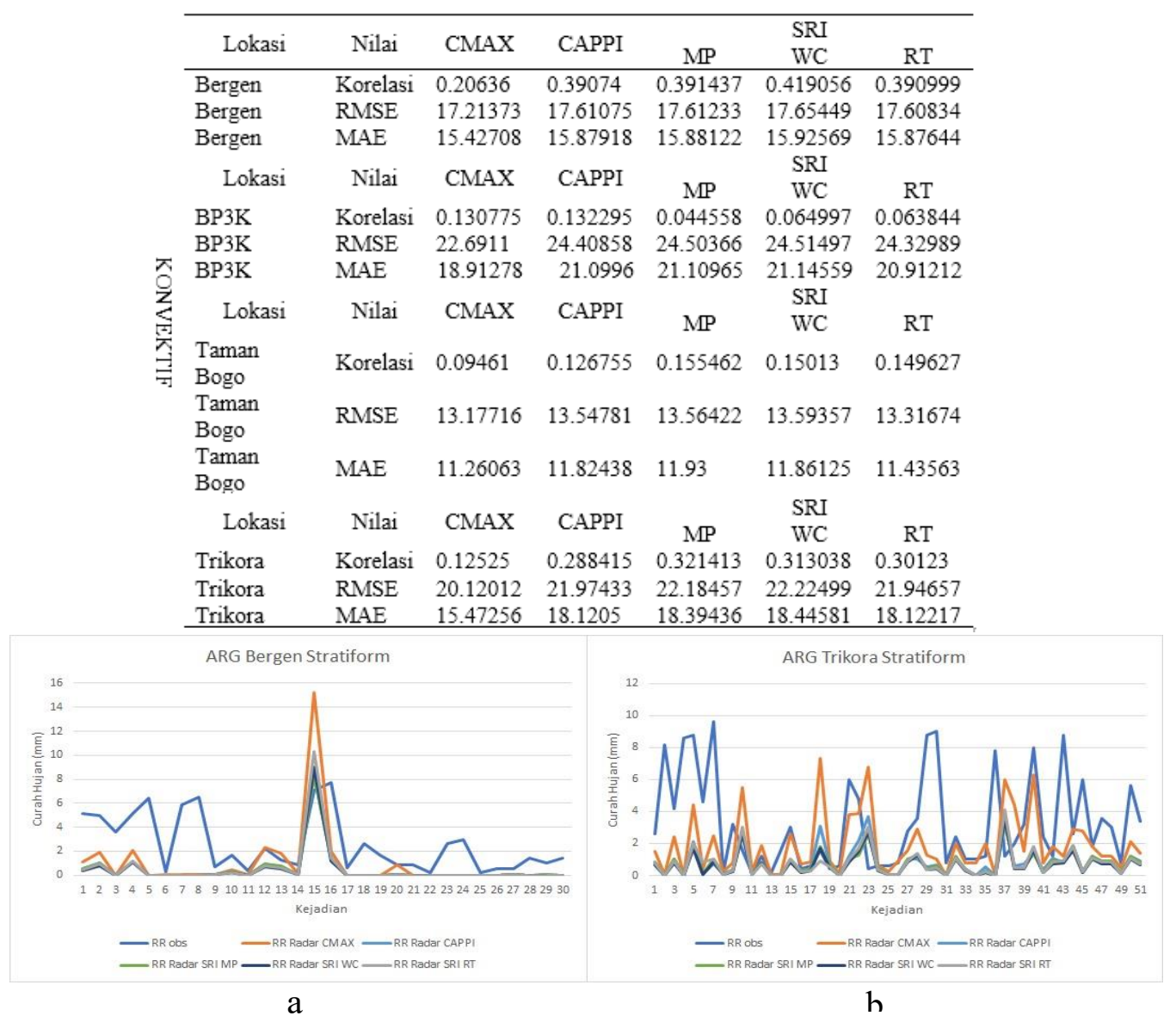

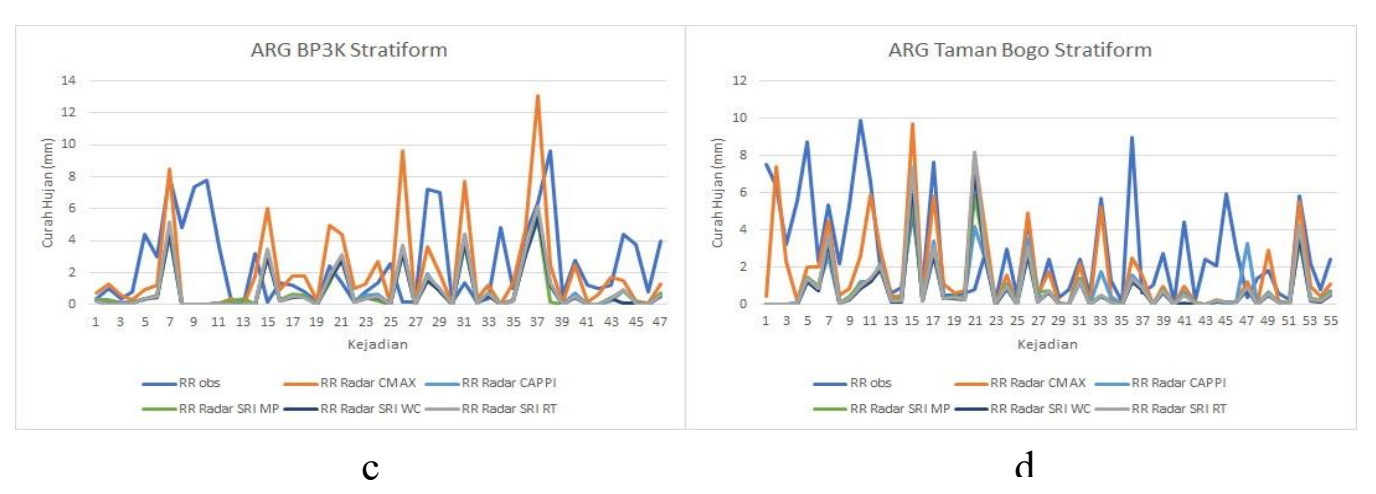

Gambar 4. Perbandingan estimasi curah hujan radar dan pengamatan untuk hujan tipe awan stratiform pada masing-masing daerah ARG Bergen (a), ARG Trikora (b), ARG BP3K (c) dan ARG Taman Bogo (d) 
Gambar 4 merupakan grafik perbandingan curah hujan hasil estimasi radar dan curah hujan hasil pengamatan untuk tipe awan hujan stratiform di 4 lokasi pengamatan yaitu di ARG bergen, ARG BP3K, ARG Trikora, dan ARG Taman Bogo. Jika dibandingkan dengan grafik perbandingan curah hujan pada awan konvektif, pola yang terlihat pada grafik tersebut cenderung lebih beragam. Sebagian hasil estimasi curah hujan radar menunjukkan nilai underestimate dan sebagian lainnya menunjukkan hasil yang overestimate pada 4 lokasi pengamatan. Terlihat pada beberapa kejadian hujan, estimasi curah hujan radar melebihi batas $10 \mathrm{~mm} / \mathrm{jam}$ yang mana masuk dalam kategori hujan konvektif seperti pada produk CMAX di ARG BP3K dan Bergen. Berdasarkan grafik perbandingan di atas, didapatkan nilai-nilai korelasi, RMSE, dan MAE untuk setiap produk di tiap lokasi pengamatan seperti yang ditunjukkan oleh tabel 5.

Tabel 5. Nilai RMSE, MAE dan korelasi dari masing-masing produk di setiap titik pengamatan pada tipe awan stratiform

\begin{tabular}{|c|c|c|c|c|c|c|}
\hline Lokasi & Nilai & CMAX & CAPPI & \multicolumn{3}{|c|}{ SRI } \\
\hline Bergen & Korelasi & 0.449182 & 0.47123 & 0.469377 & 0.452772 & 0.452846 \\
\hline Bergen & RMSE & 3.150276 & 2.960214 & 2.961632 & 3.011472 & 3.019046 \\
\hline Bergen & MAE & 2.221397 & 2.177127 & 2.179233 & 2.23792 & 2.258777 \\
\hline Lokasi & Nilai & CMAX & CAPPI & (P & SRI & \\
\hline$B P 3 \mathrm{~K}$ & Korelasi & & & $\begin{array}{c}\mathrm{NI} \\
0217642\end{array}$ & WC & KI \\
\hline BP3K & RMSE & 3405 & & 3.120658 & 3.208506 & 3050651 \\
\hline BP3K & MAE & 2.307791 & 2.161413 & 2.165155 & 2.195945 & 2.145658 \\
\hline J 0 k & Nila & CMA & CAP & & SRI & \\
\hline Lond ta & Nite & C & CAFTI & MP & WC & RT \\
\hline Taman Bogo & Korelasi & 0.478304 & 0.334648 & 0.293793 & 0.247408 & 0.255038 \\
\hline Taman Bogo & RMSE & 2.720238 & 3.135022 & 3.212156 & 3.329735 & 3.302971 \\
\hline Taman Bogo & MAE & 0.894834 & 1.12887 & 1.142642 & 1.199895 & 1.179074 \\
\hline Lokasi & Nilai & CMAX & CAPPI & MP & $\begin{array}{l}\text { SRI } \\
\text { WC }\end{array}$ & RT \\
\hline Trikora & Kore & 0.08 & 0.000 & 0.035818 & 0.032404 & 0.06441 \\
\hline Trikora & RMSE & 3.570314 & 3.879875 & 3.878159 & 3.933504 & 3.873942 \\
\hline Trikora & MAE & 2.418275 & 2.749006 & 2.732839 & 2.808545 & 2.77081 \\
\hline
\end{tabular}

Berdasarkan tabel 5, performa produk menunjukkan hasil yang berbeda-beda di tiap lokasi pengamatan dilihat dari nilai korelasi, RMSE, dan MAE. Di ARG Bergen, performa terbaik ditunjukkan oleh produk CAPPI yang mana nilai korelasinya mencapai 0.47 sedangkan produk-produk lain menunjukkan nilai korelasi yang cukup berdekatan. Sementara itu, jika dbandingkan dengan estimasi curah hujan untuk awan konvektif nilai RMSE dan MAE lebih kecil, yang artinya semakin mendekati nol maka error yang dihasilkan semakin kecil. Di lokasi pengamatan ARG BP3K, produk SRI-RT menunjukkan nilai yang paling baik dibandingkan yang lainnya dengan korelasi 0.284 dengan nilai RMSE dan MAE yang juga lebih rendah dibandingkan produk-produk lainnya. Sementara itu di ARG Taman Bogo, produk CMAX menunjukkan hasil yang terbaik dengan nilai korelasi 0.478 dengan nilai RMSE dan MAE yang lebih kecil dibandingkan dengan produk-produk lainnya. Terakhir, di ARG Trikora beberapa produk yang diuji menunjukkan nilai korelasi yang sangat rendah jika dibandingkan dengan lokasi pengamatan lainnya dimana nilai korelasi tertinggi didapat pada produk CMAX hanya mencapai 0.088 dan juga dengan nilai RMSE dan MAE yang lebih rendah dibandingkan produk lain. Dari 3 hubungan Z-R yang digunakan, hubungan Z-R Marshall-Palmer (MP) dan Rosenfield Tropical (RT) cukup berimbang dimana masingmasing menunjukkan performa terbaik di 2 lokasi pengamatan. 
Secara keseluruhan, pada kejadian hujan konvektif, estimasi curah hujan radar menunjukkan niilai yang lebih rendah dibandingkan dengan nilai curah hujan hasil pengamatan (underestimate). Bahkan, pada beberapa kejadian hujan, estimasi curah hujan radar menghasilkan nilai nol seperti pada lokasi ARG Bergen. Sedangkan pada kejadian hujan stratiform, terdapat beberapa kejadia hujan dimana hasil estimasi curah hujan radar menunjukkan hasil yang lebih tinggi dibandingkan dengan hasil pengamatan (overestimate).

Dalam menentukan produk radar dan hubungan Z-R terbaik, dapat dilihat dari nilai korelasi, RMSE, dan MAE yang dihasilkan terhadap curah hujan pengamatan. Semua produk radar yang digunakan menghasilkan nilai korelasi positif yang artinya secara umum kenaikan curah hujan pada pengamatan juga diikuti dengan kenaikan estimasi curah hujan radar. Namun semua produk radar yang dihasilkan memiliki korelasi yang lemah. Beberapa hal yang mempengaruhi antara lain adalah jumlah data yang dikorelasikan dan perbedaan signifikan antara nilai estimasi curah hujan radar dan pengamatan. Adanya kejadian hujan dengan nilai curah hujan yang sangat tinggi sementara nilai estimasi curah hujan radar yang rendah berdampak pada rendahnya nilai korelasi yang dihasilkan. Selanjutnya adalah adanya attenuasi atau pelemahan energi yang diemisikan oleh radar saat melaju di atmosfer membuat energi dari yang diterima kembali oleh radar lebih rendah sehingga mengurangi pembacaan estimasi curah hujan radar. Selain itu, terdapat adanya perbedaan mekanisme pengukuran curah hujan pengamatan di permukaan dengan estimasi curah hujan radar. Radar mengukur intensitas presipitasi pada awan sebelum hujan turun, sedangkan alat penakar hujan di permukaan mengukur curah hujan yang jatuh di titik pengamatan. Banyak faktor yang mempengaruhi tetes hujan sebelum jatuh ke permukaan bumi, salah satunya adalah faktor angin. Adanya dorongan angin membuat tetes hujan tidak jatuh tegak lurus pada penakar hujan di permukaan.

Pada kasus hujan konvektif, hubungan Z-R WC menunjukkan hasil yang lebih baik dibanding dua hubungan Z-R lainnya, namun kurang baik untuk kasus hujan stratiform. Ini karena hubungan Z-R W-C ditunjukkan untuk mengestimasi curah hujan awan konvektif kuat, dimana banyak terjadi proses konvektif kuat di Lampung. Sedangkan untuk kejadian hujan tipe awan stratiform Z-R M-P menunjukkan hasil yang lebih baik dibanding dua hubungan Z-R lainnya. Ini sesuai dengan rekomendasi ROC (1999) yang merekomendasikan hubungan Z-R M-P untuk mengestimasi hujan tipe awan stratiform yang mana lebih banyak menghasilkan tetes berukuran besar dan menghasilkan lebih sedikit ukuran tetes kecil daripada awan konvektif.

\section{KESIMPULAN}

Berdasarkan hasil penelitian yang didapat, produk yang baik digunakan pada kejadian hujan tipe awan konvektif di daerah Lampung adalah produk SRI. Sementara itu untuk hubungan Z-R paling represetatif untuk kejadian hujan tipe awan konvektif adalah hubungan Z-R WSR-88D Convective (W-C). Sedangkan untuk kejadian hujan tipe awan stratiform produk yang paling representatif adalah CMAX. Sementara itu, untuk hubungan Z-R paling representatif untuk kejadian hujan tipe awan stratiform adalah Hubungan Z-R MarshallPalmer (M-P).

\section{DAFTAR PUSTAKA}

Alfieri, L., Claps, P. \& Laio, F. (2010). Timedependent Z-R relationships for estimating rainfall fields from radar measurements. Natural Hazards and Earth System Sciences, 10, pp 149-158. 
Dewi, N. K. T. (2018). Estimasi Curah Hujan Kuantitatif Berbasis Data Radar Cuaca di Pangkalan Bun (Skripsi yang tidak dipublikasikan). Sekolah Tinggi Meteorologi Klimatologi dan Geofisika, Tangerang Selatan.

Kusuma, I.K.N. A. (2016). Pengaruh Pengklasifikasian Tipe Awan Hujan terhadap Keakurasian Hubungan Z-R (Reflektivitas-Rain Rate) untuk Estimasi Hujan di Wilayah Jakarta dan Sekitarnya (Skripsi yang tidak dipublikasikan). Sekolah Tinggi Meteorologi Klimatologi dan Geofisika, Tangerang Selatan.

Nzeukou, A. \& Sauvageot, H. (2004). Raindrop Size Distribution and Radar Parameters at Cape Verde. Journal of Applied Meteorology, 43, 90 - 105.

Radar Operations Center (ROC). (1999) Guidance on selecting Z-R relationships. Diperoleh dari www.roc.noaa.gov.

Rosenfeld, D. \& Ulbrich, C. W. (2002). Cloud microphysical properties, processes, and rainfall estimation opportunities.

Swarinoto, Y. S. \& Sugiyono. (2011). Pemanfaatan suhu udara dan kelembapan udara dalam persamaan regresi untuk simulasi prediksi total hujan bulanan di Bandar Lampung. Jurnal Meteorologi dan Geofisika, 12(3), 269-279.

Tokay, D. \& Short, A. (1996). Evidence from Tropical raindrop spectra of the origin of rain from stratiform versus Convective clouds. J. Appl. Meteor., 35(3), 355-371.

Triatmodjo, B. (2008). Hidrologi Terapan. Yogyakarta, Indonesia: Beta Offset.

Usman, H. \& Akbar, R. P. S. (2011). Pengantar Statistika (2 ${ }^{\text {nd }}$ ed). Jakarta, Indonesia: Bumi Aksara.

Wardoyo, E. (2015). Pengantar Aplikasi Radar Cuaca, Tangerang Selatan.

Waskita, T. P. (2017). Estimasi Curah Hujan Menggunakan Radar Cuaca Polarisasi Tunggal untuk Tipe Hujan Awan Stratiform dan Konvektif di Bima (Skripsi yang tidak dipublikasikan). Sekolah Tinggi Meteorologi Klimatologi dan Geofisika, Tangerang Selatan.

Wilks, D.S. (1995). Statistical methods in the atmospheric sciences. San Diego: Academic Press Inc. 